\title{
TEOLOGI POLITIK UNTUK KEADILAN \\ Respons Teologis Gereja di Tengah Menguatnya Politik Identitas
}

Pdt. Dr. Djoys Anneke Rantung, M.Th. ${ }^{1}$

Djoys.anneke@gmail.com

\begin{abstract}
Abstrak
Dalam konteks situasi kontemporer gereja hadir dan bergumul dengan tantangantantangannya. Ada tiga tantangan sekaligus yang didapati oleh penulis, yakni pertama, gereja berada di tengah situasi menguatnya politik identitas yang muncul pasca orde baru. Kedua, gereja bergumul dengan dirinya sendiri yang juga dibayang-bayangi oleh para politisi dari kalangan umatnya. Ketiga, gereja bergumul dengan idealisme Injil Yesus Kristus dalam menghadirkan keadilan sosial dan perdamaian bagi dunia.

Penulisan ini mengangkat pergumulan-pergumulan tersebut dan meletakkan teologi politik sebagai praksis gereja untuk proklamasi Injil Yesus Kristus dalam upaya memahami secara teologis cita-cita Indonesia merdeka, yaitu keadilan sosial bagi seluruh rakyat Indonesia. Tulisan ini kemudian berkembang hingga pada pemahaman, bahwa masalah politik identitas yang berorientasi pada kekuasaan hanya untuk kelompok identitas tertentu direspon oleh gereja dengan teologi politik yang berorientasi pada keadilan sosial bagi semua demi perdamaian dan kesejahteraan.

Model penelitian yang digunakan dalam penelitian ini adalah kualitatif, berdasarkan hasil studi pustaka berbagai sumber dalam meneliti teologi politik untuk keadilan sebagai respon gereja di tengah menguatnya politik identitas. Maksud dan tujuan penelitian ini untuk mengetahui tantangan-tantangan yang dihadapi gereja dengan menguatnya politik identitas yang muncul pasca orde baru, pergumulan gereja yang dibayang-bayangi oleh para politisi dari kalangan umatnya dan gereja yang bergumul dengan idealisme injil Yesus Kristus dalam menghadirkan keadilan sosial bagi perdamaian dunia. Metode pengumpulan data yang digunakan adalah kualitatif deskriptif. Hasil penelitian ini adalah teologi politik untuk keadilan sosial untuk tujuan keadilan sosial. Memperjuangkan hak-hak hidup orang lemah, miskin, tertindas dan mendatangkan keadilan dan kesejahteraan sebagaimana tujuan injil Yesus Kristus dalam menghadirkan keadilan sosial dan menghadirkan perdamaian bagi semua orang.
\end{abstract}

Kata-kata kunci: politik identitas, gereja, teologi politik, keadilan sosial

\section{Pendahuluan}

Tujuan dan cita-cita luhur kehidupan bangsa Indonesia adalah keadilan sosial. Hal ini dijadikan sebagai dasar negara yang dituliskan dalam Sila kelima Pancasila "Keadilan Sosial bagi seluruh Rakyat Indonesia". Jika dipahami secara utuh bersama empat sila lainnya, maka sila kelima ini dapat dikatakan sebagai tujuan dari ke-semua prinsip dalam Pancasila, terutama ketika hal ini diletakkan dalam pembahasan mengenai politik sebagai strategi atau cara menata kehidupan bersama. Cita-cita kehidupan bersama ini melembaga dalam negara, lalu upaya-upaya pencapaiannya dijalankan dalam suatu sistem politik modern, yaitu demokrasi.

\footnotetext{
${ }^{1}$ Dosen Pasca Sarjana Program Pendidikan Agama Kristen Universitas Kristen Indonesia
} 
Ideal adanya sebuah negara adalah untuk mewujudkan keadilan, perdamaian dan kesejahteraan bagi semua warga negara. Ideal ini juga tertera di dalam Pembukaan UUD 1945. Melalui adanya negara Indonesia merdeka, maka akan terwujud kebebasan, keadilan, kesejahteraan, perdamaian dan kesetaraan. Dengan begitu, semua proses dan lembaga yang menjalankan tugas negara, dasar dan tujuannya adalah untuk mencapai visi bernegara itu. Semua upaya, langkah, strategi, metode untuk menuju ke visi bernegara yang ideal, itulah yang disebutkan dengan 'politik'. Namun fakta menunjukkan, bahwa politik yang baik itu karena ia bertujuan untuk mencapai visi yang ideal tidaklah monolitik. Demokrasi justru memberi ruang kebebasan kontestasi bagi kelompok-kelompok politik yang berdasar pada macam-macam ideologi. Tujuan kontestasi ini adalah untuk merebut kekuasaan, yang secara normatif politik juga dimengerti sebagai cara atau teknik mengelola kekuasaan. Namun, istilah 'politik kekuasaan' sering digunakan untuk menunjuk pada orientasi kelompok-kelompok politik untuk merebut kekuasaan dalam rangka untuk berkuasa demi mencapai kepentingannya sendiri.

Otonomi daerah sebagai amanat reformasi, di satu pihak bertujuan untuk efisiensi dan efektivitas pelaksanaan politik, namun pada pihak lain telah memunculkan masalah dalam hal basis dan orientasi pada politik praktis. Identitas agama, misalnya telah menjadi salah satu basis identitas dalam upaya untuk memenangkan pemilihan umum.

Tulisan ini membahas tentang posisi dan peran gereja di tengah geliat politik identitas. Permasalahan teologis dan praktis yang dihadapi oleh gereja, di satu pihak secara nasional ia diperhadapkan dengan politik identitas yang menyasar kelompok-kelompok minoritas secara identitas, namun sekaligus juga ia bergumul dengan politisasi terhadap simbol dan massa umat untuk tujuan politik kekuasaan dan pada lain pihak yang terkait erat dengan itu adalah pergumulan terhadap panggilannya untuk memperjuangkan keadilan sosial.

\section{Konsep Politik Identitas dan Keadilan Sosial \\ a. Politik Identitas}

Politik identitas (political identity) mesti dibedakan dengan identitas politik (political of identity). Menurut Muhtar Haboddin mengutip Martin L. Sinaga, identitas politik adalah konstruksi yang menentukan posisi kepentingan subjek di dalam ikatan suatu komunitas politik. Sementara politik identitas mengacu pada mekanisme pengorganisasian identitas, baik identitas politik maupun identitas sosial sebagai sumber dan sarana politik. ${ }^{2}$ Politik identitas memainkan peranan penting yang menentukan posisi seseorang dalam mencapai tujuan.

Agnes Heller juga seperti dikutip Muhtar Haboddin mendefinisikan politik identitas sebagai gerakan politik yang memberi perhatian terhadap perbedaan sebagai kategori politik yang utama. Sementara Donald L. Morowitz menegaskan bahwa dengan politik identitas maka akan tercipta garis tegas dalam menentukan siapa yang akan disertakan dan siapa yang akan ditolak. Dari kedua definisi tersebut, maka menurut Muhtar Haboddin politik identitas adalah politik perbedaan. ${ }^{3}$ Kajian Ubed Abdilah S. menegaskan pengertian di atas dengan mengatakan, "Politik identitas adalah nama lain dari biopolitik dan politik

\footnotetext{
${ }^{2}$ Muhtar Haboddin, Politik Primordialisme: dalam Pemilu di Indonesia, (Malang: Universitas Brawijaya Press, 2015), 21.

${ }^{3}$ Muhtar Haboddin, Politik Primordialisme...21, 22.
} 
perbedaan." Biopolitik berbasis pada perbedaan-perbedaan yang timbul dari perbedaan tubuh. Lalu politik identitas yang lebih luas, adalah politik yang berdasarkan identitas etnis. ${ }^{4}$ Menurut Ubed Abdilah S., politik identitas sebagai politik perbedaan sesungguhnya merupakan wacana baru dalam kajian ilmu politik. Dalam perkembangannya, politik identitas menunjuk pada politik yang fokus utama kajian dan permasalahannya pada perbedaan-perbedaan gender, politik etnis, politik perbedaan agama, kepercayaan dan bahasa. ${ }^{5}$

Secara konseptual, politik identitas adalah pemikiran dan praktik politik untuk merebut dan atau mempertahankan posisi berkuasa sekelompok orang sebagai kelompok politik, baik secara konstitusional dalam mekanisme demokrasi, seperti pemilihan umum atau praktek politik elektoral pada berbagai bentuk dan tingkatan yang menggunakan perbedaan-perbedaan identitas. Perbedaan identitas digunakan sebagai sumber dan sarana politik yang tujuannya untuk kekuasaan segelintir orang atau elit politik. Politik identitas hanya memanfaatkan 'identitas' tertentu untuk tujuan berkuasanya. Namun yang menjadi persoalan apakah para elit politik itu benar-benar sedang memaknai esensi yang dikandung oleh identitas yang dimaksud? Masalah lain, adalah siapa yang paling berhak mengklaim 'identitas' untuk tujuan politik praktis sebab identitas sosial, etnis dan agama sesungguhnya tidak tunggal oleh sebab itu ia tidak dapat diklaim oleh kelompok tertentu. Dalam praktek politik bernegara, politik identitas dalam pengertian tersebut agaknya bermasalah, selain pada arti 'identitas' itu sendiri, tapi terutama pada tujuan berdemokrasi atau kehidupan bernegara. Sebab, politik secara normatif bertujuan untuk mengelola atau menata kehidupan bersama untuk mencapai tujuan bersama dalam kepelbagaian, yaitu keadilan sosial.

\section{b. Keadilan Sosial}

Konsep tentang 'keadilan sosial' dalam konteks Indonesia, secara historis dapat ditelusuri dalam Pidato Soekarno 1 Juni 1945 yang kemudian dikenal sebagai hari lahir Pancasila. Naskah lengkapnya terdokumentasi dalam buku Risalah Sidang BPUPKI dan Panitia Persiapan Kemerdekaan Indonesia (PPKI) yang diterbitkan Sekretariat Negara RI tahun 1995. Pidato Soekarno ini disampaikan pada sidang BPUPKI dalam suasana persiapan untuk menyatakan Negara Indonesia Merdeka. Dalam pidatonya, "Kita hendak mendirikan suatu negara 'semua buat semua'." Indonesia merdeka, bagi Soekarno adalah untuk semua warga negara ini. Berkaitan dengan dasar itu, Soekarno mengusulkan agar hal pertama dalam dasar negara Indonesia merdeka adalah 'kebangsaan' yang terbuka bergaul dengan bangsa-bangsa lain. Sehingga menyusul usulan berikut, yaitu internasionalisme. Lalu, sila berikut adalah pemusyawaratan perwakilan. Lalu Soekarno datang dengan konsepnya mengenai 'kesejahteraan sosial'. Soekarno menegaskan, kesejahteraan sosial adalah "prinsip tidak akan ada kemiskinan di dalam Indonesia Merdeka." Di dalam prinsip ini, Soekarno hendak menyatakan tentang substansi demokrasi, yaitu keadilan ekonomi dan keadilan politik, atau keadilan sosial bagi seluruh rakyat Indonesia. Itulah rumusan sila ke lima yang ditetapkan kemudian. ${ }^{6}$ Soekarno menegaskan itu dengan berkata,

\footnotetext{
${ }^{4}$ Ubed Abdilah S., Politik identitas Etnis: Pergulatan Tanda Tanpa Identitas, (Magelang: Penerbit Yayasan Indonesiatera, 2002), 16.

${ }^{5}$ Ubed Abdilah S., Politik identitas Etnis....22.

${ }^{6}$ Bur Rasuanto, Keadilan Sosial, Pandangan Deontologis Rawls dan Habermas Dua Teori Filsafat Modern, (Jakarta: PT. Gramedia Pustaka Utama, 2005), 208-209.
} 
Saudara-saudara, badan permusyawaratan yang akan kita buat, hendaknya bukan badan permusyawaratan politieke democratie saja, tetapi badan yang bersama dengan masyarakat dapat mewujudkan dua prinsip: politieke rechtvaardigheid dan sociale rechtvaardigheid (keadilan politik dan keadilan sosial, dalam bahasa Belanda-Ed.). ${ }^{7}$

Jadi, konsep keadilan sosial, baik menurut naskah pidato Soekarno 1 Juni maupun naskah Pancasila yang disepakati kemudian, keduanya menegaskan prinsip makna Indonesia Merdeka atau cita-cita dari berdirinya Indonesia. Keadilan sosial ini berjalan bersama dengan wawasan kebangsaan bahwa semua orang yang berbeda-beda bangsa adalah warga negara Indonesia yang mekanisme-mekanisme politik dijalankan secara musyawarah. Soekarno pada dasarnya sejalan dengan Hatta mengenai konsep keadilan sosial ini. Hatta menerima pengakuan hak-hak individu. Bahwa pengakuan hak-hak politik rakyat, seperti berkumpul dan mengeluarkan pendapat semata-mata adalah prinsip penghormatan terhadap manusia sebagai makhluk moral. ${ }^{8}$

Dengan mengacu dari pemikiran Soekarno dan juga Hatta sebagai gagasan-gagasan awal dalam konteks Indonesia, maka 'keadilan sosial' adalah esensi dari kehidupan bernegara Indonesia merdeka. Keadilan sosial bagi seluruh rakyat Indonesia adalah keadilan ekonomi, politik, hukum dan hak-hak asasi bagi seluruh warga Indonesia. Hal ini memberi dasar bagi praktek bernegara yang menyatakan bahwa setiap orang yang adalah warga atau kelompok-kelompok warga negara yang melekat padanya memiliki identitas secara sama atau setara.

\section{Gereja dalam Pergumulan Politik Identitas}

Dalam praktiknya, politik sangat dekat dengan kekuasaan. Memang secara teoritiknormatif, pengertian politik adalah teknik atau strategi untuk mengelola kekuasaan demi keadilan dan kesejahteraan bersama. Saut Hamonangan Sirait menyimpulkan bahwa, politik adalah untuk, "perwujudan kedaulatan rakyat melalui pembuatan keputusan yang dilakukan rakyat bagi kehidupan dan pencapaian cita-cita bersama." ${ }^{\prime 9}$ Namun, dalam praktiknya di Indonesia terutama di masa orde baru, politik cenderung untuk melayani penguasa dan kekuasaan sekelompok orang. Gejala di era pasca orde baru, sepertinya orientasi politik pada kekuasaan, bukan lagi pada rezim berkuasa secara monolitik namun pada kelompokkelompok politik tertentu, yaitu partai politik atau kelompok-kelompok yang berusaha mempengaruhi kebijakan negara yang menggunakan identitas agama dan etnis.

Politik dalam praktik tersebut tampaknya sangat dekat dan bahkan identik dengan kekuasaan. Kekuasaan itu sendiri, sejatinya abstrak dan netral. Namun, seperti pendapat yang dikemukakan M. Alfan Alfian M, kekuasaan itu “...bisa dipakai untuk kebaikan dan kesejahteraan atau sebaliknya disalahgunakan alias diselewengkan untuk kepentingan si penggenggam kekuasaan."10 Oleh karena kekuasaan itu abstrak dan netral, maka fungsi dan dampaknya tergantung dari pihak yang menjalankannya.

\footnotetext{
${ }^{7}$ Bur Rasuanto, Keadilan Sosial, ...208

8 Bur Rasuanto, Keadilan Sosial, Pandangan Deontologis Rawls dan Habermas Dua Teori Filsafat Modern, (Jakarta: PT. Gramedia Pustaka Utama, 2005), 208, 209.

${ }^{9}$ Saut Hamonangan Sirait, Politik Kristen di Indonesia: Suatu tinjauan etis, (Jakarta: BPK Gunung Mulia, 2000), 29

${ }^{10}$ M. Alfan Alfian M., Menjadi pemimpin politik: perbincangan kepemimpinan dan kekuasaan, Jakarta: Gramedia Pustakan Utama, 2009), 231.
} 
Politik Indonesia pasca keruntuhan rezim orde baru 1998, di satu pihak membawa angin segar bagi proses-proses demokrasi di Indonesia. Politik tidak lagi monolitik, tapi menjadi beragam. Setiap warga negara seolah mendapat kembali hak politiknya melalui pemilihan umum. ${ }^{11}$ Namun begitu desentralisasi yang telah menghasilkan banyak daerah administrasi baru, "lebih pada berpindahnya sentralisme politik dari pemerintah pusat ke pemerintah daerah. ${ }^{12}$ Dampak dari desentralisasi tersebut adalah menguatnya politik identitas. Menurut Laode Machdani Afala, gerakan politik identitas yang mulai menguat akibat runtuhnya rezim Orde Baru secara intens digunakan oleh para aktor politik untuk pembagian kekuasaan, merebut dan mengamankan sumber-sumber pendanaan yang dibangun melalalui jaringan patrimonial. ${ }^{13}$ Dengan desentralisasi, maka pemusatan kekuasaan ke Jakarta atau pusat kekuasaan selama orde baru memudar. Muhtar Haboddin mengatakan, dengan runtuhnya kekuasaan orde baru yang sentralistis, bangsa ini berhadapan dengan gerakan kedaerahan yang mengambil seting politik etnisitas yang merupakan bagian dari politik identitas sebagai basis gerakan politiknya. Menurutnya, merujuk dari pendapat sejumlah pengamat, "...gerakan politik identitas kian banyak dipakai oleh para politisi dan penguasa di tingkat lokal untuk mendapatkan kue kekuasaan, baik bidang politik maupun ekonomi". ${ }^{14}$ Senada dengan Laode Machdani Afala, menurut Muhtar Haboddin, gejala ini muncul sebagai konsekuensi dari desentralisasi.

Gereja dan orang-orang Kristen sebagai bagian dari politik Indonesia, secara normatif adalah bagian sah dari politik kenegaraan yang setara dengan kelompok warga negara yang lain. Namun, dalam konteks menguatnya politik identitas, orang-orang Kristen terkonstruksi menjadi 'kelompok minoritas' secara nasional, dan di wilayah tertentu adalah 'kelompok mayoritas'. Secara nasional maupun lokal, dengan menguatnya 'politik identitas', maka baik secara politik, sosial dan ekonomi tercipta segrasi antara kelompok-kelompok masyarakat yang berbeda identitas. Ketidakadilan dalam bentuk dikriminasi menyasar kelompokkelompok minoritas identitas. Pergumulan gereja dengan politik identitas berdimensi ganda. Pada hal pertama bergumul dengan diskriminasi yang dialami oleh warga negara yang memiliki identitas Kristen atau gereja secara umum. Pada hal kedua bergumul dengan dirinya sendiri dalam menyikapi kecenderungan kalangan elit gereja atau warga Kristen yang memanfaatkan simbol dan jaringan umat sebagai massa politik untuk merebut kekuasaan. Sementara itu terdapat ideal politik Kristen yang mesti dijalankan oleh gereja, yaitu peran kenabian untuk bersama-sama dengan kelompok-kelompok warga negara lain dalam memperjuangkan keadilan sosial. Ini pergumulan tersendiri bagi gereja dalam mengembangkan teologi yang transformatif dalam kehadirannya di tengah masyarakat.

Gereja akhirnya bergumul dengan tiga hal itu sekaligus. Ini pergumulan rangkap gereja di tengah kehadirannya dalam politik Indonesia. Meski nanti menguat pasca orde baru, namun politik identitas atau dalam istilah lain disebut juga politik aliran sebenarnya adalah bagian dari sejarah politik Indonesia. Jelang Indonesia merdeka, pembahasan alot dalam sidang-sidang BPUPKI adalah apakah negara berdasarkan agama atau negara kebangsaan. Di era orde lama sepertinya aliran yang kuat mendominasi dinamika politik Indonesia kala itu adalah, Islam, Nasionalisme, Sosialisme. Aslich Maulana dalam membahas politik aliran di Indonsia, misalnya mengutip Herbetz Feith dan Lance Castles yang

\footnotetext{
${ }^{11}$ Budi Winarno, Sistem Politik Indonesia Era Reformasi, (Jakarta: Gramedia Pustaka Utama, 2007), 55, 56.

12 Winarno, Sistem Politik Indonesia..., 79.

${ }^{13}$ Laode Machdani Afala, Politik Identitas di Indonesia, (Malang: Universitas Brawijaya Press, 2018), 4.

${ }^{14}$ Muhtar Haboddin, "Menguatnya Politik Identitas di Ranah Lokal" dalam Jurnal Studi Pemerintahan, Vol.3 No.1 Februari 2012: 117.
} 
memetakan pemikiran politik antara tahun 1945-1965 dengan menyebut setidaknya lima basis ideologi politik. Masing-masing: komunisme, nasionalisme radikal, sosialisme demokrat, Islam tradisional-modern, dan Tradisionalisme Jawa. ${ }^{15}$ Di mana posisi gereja atau Kristen?

Kristen kenyataannya bukan sebagai ideologi politik dominan, meski bukan berarti tanpa kekuatan, sikap dan posisi dalam dinamika politik Indonesia sejak negara ini berdiri hingga kini. Di era orde lama, politik gereja, terutama Protestan melembaga dalam Partai Kristen Indonesia (Parkindo). Dalam Pemilu yang disebut-sebut paling demokratis tahun 1955, perolehan suara Parkindo menempat urutan ke enam dengan jumlah suara 1.003.326 (2,66 persen) dengan jumlah kursi 8 . Di era orde baru, dalam difusi partai politik, politik Kristen melebur dalam partai nasionalis Partai Demokrasi Indonesia (PDI), sementara politik Islam melebur dalam Partai Persatuan Pembangunan (PPP).

Secara sederhana dapat disimpulkan, bahwa di era orde baru, politik Kristen menyesuaikan dengan ideologi negara atau bahkan rezim penguasa, dan secara umum berusaha mencitrakan diri sebagai agama yang nasionalis. Lihat misalnya tema-tema diskusi dan pokok-pokok teologis yang dirumuskan yang cenderung menyesuikan dengan politik tunggal rezim orde baru atau juga nasionalisme pasca orde baru, yaitu 'gereja dan Pancasila, 'gereja dan Pembangunan', dlsb. ${ }^{16}$ Namun, terhadap dinamika politik elektoral kontemporer terdapat beragam respon gereja lokal-lokal dalam praktiknya di tengah masyarakat. Meski begitu, Persekutuan Gereja-gereja di Indonesia (PGI), terutama dalam pokok-pokok yang dirumuskan dalam Dokumen Keesaan Gereja tetap konsisten dengan Pancasila, Kemajemukan, Nasionalisme dan selalu menghimbau gereja-gereja anggotanya untuk tidak terjebak pada politik sektarian, primodialisme atau dengan kata lain berusaha menghindar dari politik identitas.

Sikap politik itu, sekaligus adalah ungkapan pergumulan terhadap politik identitas yang dijalankan oleh kelompok-kelompok tertentu. Dalam Seruan Pastoralnya untuk Pilkada Serentak tahun 2015 PGI menyebut masalah antara lain, "maraknya praktik politik uang, kuatnya sentimen SARA (Suku, Agama, Ras, dan Antar-golongan) demi menggalang dukungan primordial dan sektarian," selain masalah teknis lainnya. Dalam DKG PGI 2014$2019^{17}$, disebutkan hal yang perlu diberi perhatian khusus, yaitu "Mengupayakan formasi oikoumenis yang berwawasan kebangsaan". Formasi oikumenis ini, secara teologis diberi makna sebagai "kesatuan seluruh ciptaan dalam bingkai pengharapan eskatologis akan langit dan bumi baru (Why 21:1). Arahnya adalah untuk membangun keesaan dalam konteks gerejawi maupun melakukan transformasi dalam konteks masyarakat bersama dengan kelompok-kelompok lain." Dengan demikian, wawasan kebangsaan ini dimengerti sebagai pemahaman terhadap makna kehadiran gereja di tengah masyarakat dan negara. Hal ini tentu berkaitan dengan pergumulan oikumenis lainnya, yaitu bangkitanya fundamentalisme dan sektarianisme pada semua agama. Pergumulan lain adalah masalah harapan keadilan sosial sebagai tujuan dari Indonesia merdeka. Namun, reformasi yang membuka ruang demokrasi seluas-luasnya tidak diimbangi oleh kebijakan ekonomi yang memihak rakyat banyak. Sementara itu para politisi yang bersaing dalam

\footnotetext{
${ }^{15}$ Aslich Maulana, Polarisasi Politik Aliran di Era Reformasi (Gresik: Caremedia Communication, 2018), 8

${ }^{16}$ Lihat antara lain buku Weinata Sairin, Gereja, Agama-agama dan Pembangunan Nasional, (Jakarta: BPK Gunung Mulia, Cetak Pertama 1998); Martin Sinaga, Trisno Sutanto, dkk (peny.), Pergulatan Kristen di Indonesia: Teks-teks Terpilih Eka Darmaputera, (Jakarta: BPK Gunung Mulia, 2005); dan lihat juga rumusanrumusan dalam Lima Dokumen Keesaan Gereja Persekutuan Gereja-gereja di Indonesia.

17 PGI, Dokumen Keesaan Gereja (DKG - PGI 2014-2019), (Jakarta: BPK Gunung Mulia, 2015), 18 dan 69.
} 
pemilu, baik di daerah maupun nasional, tidak segan-segan memakai baik kekuatan uang (money politics) maupun sentimen primordial (suku, agama dan kedaerahan) guna meraup dukungan. ${ }^{18}$

Desentralisasi dan amandemen UUD 1945 di awal reformasi, membuka ruang bagi elit-elit politik menggunakan isu politik identitas untuk merebut kekuasaan di level lokal maupun nasional. ${ }^{19} \mathrm{Di}$ beberapa daerah yang mayoritas penduduknya beragama Kristen, berdasarkan beberapa penelitian memperlihatkan munculnya fenomena politisasi gereja atau politik identitas yang menggunakan simbol dan basis massa umat Kristen. Politik identitas ini, selain menjadi masalah bagi visi bergereja, yaitu untuk menghadirkan shalom bagi semua orang dan sekalian alam, juga masalah bagi demokrasi itu sendiri dan terutama prinsip-prinsip Pancasila sebagai dasar negara dan politik bagi keadilan sosial.

\section{IV.Teologi Politik dan Peran Gereja untuk Keadilan Sosial}

Teologi politik dapat didefinisikan, baik sebagai teologi atau pemahaman teologis tentang pemikiran dan praktek politik, maupun sebagai sikap dan aksi politik gereja yang visinya untuk perdamaian, keadilan dan kesejahteraan bagi semua orang. Pada hal ini, teologi politik tidak dapat dikatakan sebagai politik identitas gereja yang lebih berorientasi pada kepentingan umat Kristen saja. Teologi politik pada prakteknya adalah partisipasi gereja untuk mengusahakan politik yang demokratis dalam rangka menuju keadilan sosial. Sementara keadilan sosial mestinya dimengerti secara luas. Meliputi semua dimensi dari tujuan negara, yaitu keadilan di bidang ekonomi; keadilan di hadapan hukum dan hak-hak asasi bagi setiap orang dalam keragaman identitasnya; keadilan bagi setiap warga negara dengan keragaman gendernya, dan lain sebagainya. Keadilan adalah basis dari pencapain perdamaian dan kesejahteraan.

Keadilan seharusnya bertemu visi dan misi bernegara dan bergereja atau beragama. Agama-agama bergulat dengan keadilan bagi kehidupan bersama dalam terang llahi, negara berupaya menciptakan keadilan dengan menjalankan politik. Demokrasi, sebagai sebuah sistem pengelolaan kekuasaan telah dipilih oleh Indonesia. Politik yang dijalankan mesti demokratis. Artinya, praktek pengelolaan kekuasaan ini mesti berbasiskan keadilan sosial. Rakyat atau warga negara menjadi subjek untuk menata dan mengelola sumber daya alam, relasi-relasi antar warga atau kelompok yang beragam, dan penegakan hukum. Gereja, terutama dalam konteks Indonesia menerima politik yang demokratis dalam prinsip Pancasila. Dengan demikian, teologi politik gereja untuk keadilan sosial, dalam merespon atau menghadapi politik identitas yang menguat pasca orde baru, berbasiskan visi Injil yaitu shalom dan sekaligus ideal Indonesia merdeka. Sikap dan posisi teologis sekaligus politis ini, oleh PGI menyebutnya wawasan oikumenis kebangsaan, semata-mata adalah untuk memperjuangkan keadilan sosial bagi seluruh rakyat Indonesia.

PGI dalam Pokok-Pokok Tugas Panggilan Bersama (PTPB) sebagai landasan teologis dan misiologis bagi gereja-gereja Kristen Protestan di Indonesia merumuskan landasan teologisnya sebagai berikut:

a. gereja ada karena dipanggil oleh Allah dan diutus menjadi berkat bagi segala bangsa (bdk. Kej. 12:1-3);

b. sebagai kelanjutan dari misi Kristus, maka gereja ada karena dipanggil dan diutus oleh Yesus Kristus untuk memberitakan Injil dan diberi kuasa untuk mengusir setan, sekalipun mereka berbeda latar belakang (bdk. Mrk. 3:13-19);

\footnotetext{
18 PGI, Dokumen Keesaan Gereja...62, 63

${ }^{19}$ Laode Machdani Afala, Politik Identitas...,4
} 
c. gereja dipanggil untuk menghasilkan buah (bdk. Mat.7:15-23);

d. keesaan gereja adalah juga misi supaya dunia percaya (bdk. Yoh. 17:21). ${ }^{20}$

Disebutkan, bahwa PTPB ini menggunakan pendekatan misiologis-pastoral yang berangkat dari "pemahaman tentang panggilan bersama (misi) gereja-gereja di dalam konteks pergulatan bangsa Indonesia untuk mencapai cita-cita Proklamasi Kemerdekaan 1945, Pemahaman misiologis itu menjadi pedoman langkah-langkah konkret pastoral, yakni bagaimana umat Kristen secara keseluruhan hadir dan bersaksi di dalam pergulatan bangsa tersebut. Berdasarkan pengalaman gereja-gereja selama ini, pendekatan misiologis-pastoral dipandang lebih dinamis dan kreatif." 21

Kehadiran dan misi gereja di maknai sebagai tanggung jawab politik dalam konteks kehidupan bernegara. Gereja hadir bukan hanya untuk dirinya sendiri, melainkan dalam rangka panggilan dan pengutusan untuk menjadi berkat maka ia memiliki tanggung jawab politik yang dipahami sebagai praksis teologis untuk semua orang. Dalam konteks Indonesia, semua orang itu adalah setiap warga negara yang padanya melekat identitas agama dan etnis.

Dasar pemahaman inilah yang melandasi gereja untuk merespon menguatnya politik identitas yang berorientasi pada kekuasaan dan kepentingan kelompok sendiri. Politik identitas ini seperti yang muncul dalam fenomena politik praktis bermasalah bagi ideal dan usaha pencapaian keadilan sosial bagi seluruh rakyat Indonesia. Ruang publik Indonesia adalah 'medan kesaksian' gereja untuk keadilan demi shalom. Gereja dalam teologi politiknya menyatakan kesaksian Injil dalam solidaritas untuk orang-orang yang menderita; untuk mereka yang didiskriminasi dan lebih luas untuk kehidupan bermasyarakat dan bernegara yang dalam situasi yang tidak menentu atau tidak damai.

G.P. Sindhunata, SJ, mengatakan, teologi politik berupaya solider terhadap manusia yang menderita. Ingatan terhadap sejarah penderitaan penting dalam mengembangan wawasan teologi politik. Sindhunata mengatakan:

Teologi politik adalah teologi yang merefleksikan iman sebagaimana dihayati oleh para pelakunya dalam situasi mereka yang historis dan kongkret. Materi teologi politik bukanlah pembicaraan mengenai Tuhan semata-mata melainkan iman sebagai hubungan antara manusia dan Tuhan. Namun hubungan tersebut tidak dipahaminya secara melulu abstrak-teoritis melainkan secara konkret-praktis, yakni dalam konteks sejarah hidup manusia. Jadi bagi teologi politik, hubungan manusia dan Tuhan itu tak dapat dipahami lepas dari sejarah manusia secara konkret. ${ }^{22}$

Jadi, politik identitas yang berorientasi pada kepentingan berkuasa kelompok direspon dengan teologi politik untuk pembebasan dan keadilan bagi semua. Politik identitas dalam pengertian pemikiran, cara dan strategi meraih kekuasaan yang berbasis dan untuk kepentingan identitas eksklusif bermasalah bagi politik keadilan sosial. Setiap orang dan kelompok dalam negara demokrasi semuanya adalah warga negara yang setara dan memiliki hak yang sama untuk kehidupan sosial, ekonomi, hukum dalam rangka pencapaian keadilan dan kesejahteraan.

\footnotetext{
${ }^{20} \mathrm{PGI}$, Dokumen Keesaan Gereja..., 31.

${ }^{21}$ PGI, Dokumen Keesaan Gereja..., 32.

22 G.P. Sindhunata, SJ, “ Memoria Passionis: Walter Benjamin dan Teologi Politik” dalam Teologi \& praksis komunitas post modern, (Yogyakarta: Kanisius, 1994), 214.
} 
Teologi politik menghubungkan antara iman kepada Tuhan dengan kehidupan bersama dengan harapan dan tujuan-tujuan yang dirumuskan bersama dalam mekanisme permusyawatan atau demokrasi. Teologi politik adalah praktek beriman yang merefleksikan kehidupan kongkret, sejarah dan pergulatannya yang berorientasi pada keberlanjutan kehidupan bersama. Ruang publik yang ditata oleh negara secara konstitusional adalah medan bagi gereja atau orang-orang Kristen dalam menyatakan kesaksian iman kepada Injil Yesus Kristus untuk keadilan bersama.

Terhadap orang-orang Israel yang menyamarkan ketidakadilan dalam kesalehan, nabi Amos menyerukan gugatan yang keras. Kemakmuran hanya menjadi milik para elit, dan sangatlah ironis karena semua itu mereka peroleh dari penindasan, dan ketidakadilan terhadap orang-orang lemah. Ketidakadilan ini digambarkan dengan pernyataan ini: "Dengarlah firman ini, hai lembu-lembu Basan, yang ada di gunung Samaria, yang memeras orang lemah, yang menginjak orang miskin, yang mengatakan kepada tuan-tuanmu: bawalah ke mari, supaya kita minum-minum!" (Amos 4:1). Juga dikatakan, "Hai kamu yang mengubah keadilan menjadi ipuh dan yang mengempaskan kebenaran ke tanah!" (Amos 5:7) dan "Sebab Aku tahu, bahwa perbuatanmu yang jahat banyak dan dosamu berjumlah besar, hai kamu yang menjadikan orang benar terjepit, yang menerima uang suap dan yang mengesampingkan orang miskin di pintu gerbang." (Amos 5:12) .

Nabi juga meyerukan agar orang-orang Israel 'mencari Tuhan agar mereka hidup: "Carilah yang baik dan jangan yang jahat, supaya kamu hidup; dengan demikian TUHAN, Allah semesta alam, akan menyertai kamu, seperti yang kamu katakan. Bencilah yang jahat dan cintailah yang baik; dan tegakkanlah keadilan di pintu gerbang; mungkin TUHAN, Allah semesta alam, akan mengasihani sisa-sisa keturunan Yusuf." (5: 14, 15).

Iman yang benar kepada Tuhan terimplementasi dalam keberlanjutan hidup. Iman untuk kehidupan. Tuhan berpihak kepada kehidupan, bukan kepada ketidakadilan yang mendatangkan maut. Bukan pada kesalehan palsu yang menyamarkan keserakahan dan kekuasaan kelompok sendiri. Teologi nabi Amos tentang keadilan ini memberi wawasan tentang praksis beragama yang terhubung dengan kehidupan bersama. Keadilan sosial bagi seluruh orang praksis iman dalam kehidupan sosial-politik.

Emmanuel Gerrit Singgih dalam membahas tafsiran teologi Amos mengatakan, makna konkret istilah Amos 'mencari Tuhan' bukanlah meningkatkan kegiatan-kegiatan yang bersifat dan berbentuk kerohanian. Singgih mengkritik cara gereja-gereja pada zaman orde baru yang menghindar menggumuli ketidakadilan dan ketidakbenaran dalam masyarakat dan justru hanya banyak berdoa. Hal konkret yang dimaksud oleh Singgih sebagai peran gereja dalam masyarakat dan kehidupan bernegara adalah: 'memerangi kemiskinan dan penderitaan'; 'memperjuangkan masyarakat yang adil, berkedaulatan rakyat, demokratis dan HAM'; dan 'mengakhiri konflik antar agama'. ${ }^{23}$

Hal-hal yang diuraikan di atas adalah upaya mewujudkan iman yang otentik dalam situasi nyata hidup dalam negara Indonesia. Teologi politik gereja yang bukan politik identitas itu adalah menjalankan misi Allah untuk melakukan transformasi sosial, politik dan ekonomi, hukum dan HAM demi tercapainya visi hidup bersama sebagai sesama warga negara. Hartono Budi mengatakan, 'teologi politik menekankan pentingnya kesaksian iman secara publik dan tindakan mengikuti Yesus Kristus secara politik.' Menurut Budi, seperti pendapat Moltman, bahwa teologi politik harus dibedakan secara tegas dengan upaya mempolitisir gereja, tetapi ini dimaksudkan untuk mengkristenkan eksistensi politis gereja

\footnotetext{
${ }^{23}$ Emmanuel Gerrit Singgih, Dua Konteks: Tafsir-tafsir Perjanjian Lama sebagai Respons atas Perjalanan Reformasi di Indonesia, (Jakarta: BPK Gunung Mulia, 2009)), 12-16.
} 
dan umat Kristiani. Olehnya, secara konkret dapatlah dikatakan bahwa, 'teologi politik membawa masalah sosial ke dalam gereja dan membuat gereja hadir dalam situasi manusia yang kontradiktif termasuk penderitaan manusia. ${ }^{24}$

Dua kata kunci yang menarik dari ulasan Budi di atas adalah 'publik' dan 'politik'. Iman sebagai kepercayaan dan keyakinan terhadap Tuhan mestilah mempertimbangkan ruang hidup bersama yang historis dan empirik, yaitu publik. Malah dapat dikatakan, iman yang otentik adalah ketika kepercayaan dan keyakinan terhadap Tuhan Allah benar-benar berangkat dari pergulatan konteks kehidupan. Di ruang publik, seorang Kristen hadir sebagai warga negara bersama dengan warga negara lain yang masing-masing memiliki 'iman' sendiri-sendiri. Tapi, penderitaan, ketidakadilan, diskriminasi, kemiskinan, penindasan, dan lain sebagainya itu menyasar manusia yang universal. Berbeda dengan politik identitas yang justru mengeksploitasi isu-isu ketidakadilan dihubungan dengan identitas sendiri, teologi politik berangkat dari masing-masing iman yang otentik tapi praksis teologisnya untuk keadilan dan perdamaian semua orang.

Dengan begitu, maka gereja sebagai persekutuan, meski pada hal keanggotaan ia eksklusif namun keberadaannya mestilah bersifat sosial dan politis. Artinya, berangkat kenyataan dan kesadaran bahwa gereja berada 'di tengah-tengah' masyarakat, maka seperti kata Budi, "gereja hadir dalam situasi manusia yang kontradiktif termasuk penderitaan manusia." Masalah-masalah sosial yang dialami oleh orang-orang yang memiliki identitasnya masing-masing dibawa masuk ke dalam gereja, menjadi percakapan teologis, menjadi pergumulan dan menjadi sasaran praksis teologi politik orang-orang Kristen.

\section{Penutup}

Dalam ulasan di atas telah dikaji bagaimana posisi gereja berhadapan dengan, pertama, politik identitas dari kelompok identitas mayoritas; kedua, pergumulan gereja dengan dirinya sendiri yang selalu berada dalam bayang-bayang politisasi. Respon teologis yang ditawarkan kaitan dengan dua pergumulan itu adalah dengan memahami kembali pergumulannya. Yang ketiga, yaitu praksis gereja dalam memproklasmikan idealisme Injil Yesus Kristus dalam konteks kehidupan bernegara. Metode dan strategi praksis gereja ini mesti dipahami dalam kerangka misi berwawasan oikumenis.

Teologi politik sebagai praksis teologis dalam misi berwawasan oikumenis ini sematamata adalah upaya gereja bersama-sama dengan kelompok-kelompok agama atau kelompok identitas lain dalam upaya menghadirkan keadilan sosial dan perdamaian bagi dunia. Pada hal ini idealisme Injil Yesus Kristus bertemu dengan cita-cita kemerdekaan Indonesia.

\section{Kepustakaan}

Afala, Laode Machdani. Politik Identitas di Indonesia. Malang: Universitas Brawijaya Press, 2018.

Alfian M, M. Alfan, Menjadi pemimpin politik: perbincangan kepemimpinan dan kekuasaan. Jakarta: Gramedia Pustakan Utama, 2009.

Budi, Hartono, Teologi, Pendidikan dan Pembebasan. Yogyakarta: Kanisius, 2003.

\footnotetext{
${ }^{24}$ Hartono Budi, Teologi, Pendidikan dan Pembebasan, (Yogyakarta: Kanisius, 2003), 38.
} 
G.P. Sindhunata, SJ, “ Memoria Passionis: Walter Benjamin dan Teologi Politik" dalam Teologi \& praksis komunitas post modern. Yogyakarta: Kanisius, 1994.

Haboddin, Muhtar, Politik Primordialisme: Dalam Pemilu di Indonesia. Malang: Universitas Brawijaya Press, 2015.

.., "Menguatnya Politik Identitas di Ranah Lokal" dalam Jurnal Studi Pemerintahan, Vol.3 No.1 Februari 2012: 117.

Maulana, Aslich, Polarisasi Politik Aliran di Era Reformasi. Gresik: Caremedia Communication, 2018.

Rasuanto, Bur, Keadilan Sosial, Pandangan Deontologis Rawls dan Habermas Dua Teori Filsafat Modern. Jakarta: PT. Gramedia Pustaka Utama, 2005.

Sirait, Saut Hamonangan, Politik Kristen di Indonesia: Suatu tinjauan etis. Jakarta: BPK Gunung Mulia, 2000.

PGI, Dokumen Keesaan Gereja (DKG - PGI 2014-2019). Jakarta: BPK Gunung Mulia, 2015.

Singgih, Emmanuel Gerrit, Dua Konteks: Tafsir-tafsir Perjanjian Lama sebagai Respons atas Perjalanan Reformasi di Indonesia. Jakarta: BPK Gunung Mulia, 2009. .

S, Ubed Abdilah, Politik identitas Etnis: Pergulatan Tanda Tanpa Identitas. Magelang: Penerbit Yayasan Indonesiatera, 2002.

Winarno, Budi, Sistem Politik Indonesia Era Reformasi. Jakarta: Gramedia Pustaka Utama, 2007. 